\title{
Kościół prawosławny wobec problemów współczesnego świata z perspektywy Soboru Wszechprawosławnego
}

Zamierzam poddać wstępnej analizie treść ważnego projektu dokumentu, przygotowanego na planowany w czerwcu 2016 roku Sobór Wszechprawosławny, zaaprobowanego przez zgromadzenie (synaxis) zwierzchników autokefalicznych Kościołów prawosławnych, obradujące w Chambésy (Szwajcaria) w dniach 21-28 stycznia 2016. Dokument nosi tytuł: Misja Kościoła prawosławnego w świecie wspótczesnym. Wkład Kościoła prawosławnego w osiagnięciu pokoju, sprawiedliwości, wolności, braterstwa i miłości między narodami i eliminacji rasowej i innych dyskryminacji ${ }^{1}$. Najpierw będę chciał powiedzieć kilka słów na temat historii tekstu, jego struktury, aby przejść następnie do omówienia jego tematów teologicznych.

${ }^{1}$ Por. La mission de l'Église orthodoxe dans le monde contemporain. La contribution de l'Église orthodoxe à la realisation de la paix, de la justice, de la liberté, de la fraternité et de l'amour entre les peuples et à la suppression des discriminations raciales et autres (Chambésy, 27 janvier 2016), https://mospat.ru/fr/2016/01/28/news127353/ (28.01.2016). Tłum. pol. zob. Aneks nr 7 niniejszej publikacji. 


\section{Historia dokumentu}

„Jest rzeczą naturalną - pisze ks. Tadeusz Kałużny, ekspert w tym temacie - że prawosławni czują swoją odpowiedzialność wobec problemów dzisiejszego świata i człowieka, oczekując w tym względzie odpowiedniego pouczenia i wsparcia ze strony swoich Kościołów lokalnych. Problem w tym, że Kościół prawosławny przez szereg stuleci - jak zauważa A. Schmemann - nie odczuwał potrzeby zastanawiania się nad stosunkiem do świata. Stąd też sprawa rozróżnienia pojęć 'Kościół' i 'świat' dopiero niedawno, po okresie długiego 'eklezjologicznego milczenia', 'pojawia się’ w prawosławnej teologii jako odrębny przedmiot specyficznie teologicznej refleksji” ${ }^{2}$ „Nic więc dziwnego - kontynuuje Kałużny - że w podejmowanych w tym kierunku wysiłkach ze strony lokalnych Kościołów prawosławnych istnieją pewne rozbieżności zarówno na płaszczyźnie refleksji teologicznej, jak i konkretnych form praktycznego działania. Trudności te wynikają ponadto $\mathrm{z}$ faktu, że tego rodzaju zaangażowanie się Kościołów prawosławnych dotyka zróżnicowanych porządków teologicznego, społeczno-politycznego, społeczno-ekonomicznego, społeczno-kulturowego itd. Rozumie się więc samo przez się, że pośród zagadnień uznanych za ważne dla prawosławia i wymagających wspólnego rozpatrzenia na przyszłym soborze ogólnoprawosławnym znalazła się również sprawa stosunku prawosławia wobec niektórych problemów współczesnego świata, a mianowicie pokoju, sprawiedliwości, wolności, braterstwa i miłości między narodami oraz dyskryminacji rasowej"3.

${ }^{2}$ NSO, s. 225. Zob. także publikacje przywołane w przypisie cytowanej powyżej pozycji T. Kałużnego: A. Schmemann, Problem obecności Kościoła w świecie w świadomości prawosławnej, „Novum” 12 (1978) nr 1, s. 53-54; S. Harakas, Reflections on the Ethical Dimensions of the Topics of the Great and Holy Synod, „The Greek Orthodox Theological Review" 24 (1979) nr 2-3, s. 144-155.

${ }^{3}$ NSO, s. 342. Por. Première Conférence Panorthodoxe Préconciliaire [1976], Décisions [Chambésy, 28 novembre 1976], [w:] Synodica III, s. 114; G. Lemopoulos, Quelques réflexions sur les quatre textes de la Commission interorthodoxe préparatoire (Chambésy, février 1986), „Proche-Orient Chrétienne” 35 (1986), fasc.3-4, s. 312-313. 
Bardzo wcześnie przystąpiono zatem do prac nad przyszłym dokumentem podejmującym kwestię stosunku prawosławia do świata. W rzeczywistości, chociaż w formie nieraz zróżnicowanej, prace nad takim dokumentem, podjęte zostały niemal na początku długiej - jak się miało okazać - drogi soborowej . Bardzo jasno temat ten pojawił się w katalogu z Rodos w 1961 roku5 . Kilkanaście lat później, tj. w roku 1976, zagadnienie stosunku prawosławia do problemów współczesnego świata znalazło się wśród dziesięciu tematów soborowych (temat nr 10) ${ }^{6}$. „Opracowanie tego zagadnienia powierzono Kościołom Grecji i Czechosłowacji. Na podstawie przygotowanych opracowań i zgłoszonych w toku konsultacji sugestii Międzyprawosławna Komisja Przygotowawcza, na posiedzeniu w 1986 roku, opracowała wstępny schemat dokumentu dla przyszłego soboru. Po dokonaniu drobnych poprawek projekt ten został przedłożony w październiku 1986 roku pod obrady III Ogólnoprawosławnej Konferencji Przedsoborowej, która zatwierdziła ostateczny projektu dokumentu: Wkład Kościoła prawosławnego w realizacje pokoju, sprawiedliwości, wolności, braterstwa i miłości między narodami oraz zniesienie dyskryminacji rasowej i innych"?.

Kolejna wersja tekstu dokumentu została przejęta przez V Wszechprawosławną Konferencję Przedsoborową, która obradowała w Chambésy w dniach 10-17 października 2015 roku. Obok wielu drobnych zmian, jako poważniejszą należy odnotować zmianę czy też rozbudowanie tytułu dokumentu. Wcześniejszy tytuł (Wkład Kościoła prawosławnego w realizację pokoju, sprawiedliwości, wolności, braterstwa i miłości między narodami oraz zniesienie dyskryminacji rasowej $i$ innych) został poprzedzony tytułem Misja Kościoła prawosławnego $w$ świecie współczesnym. W ostatecznej redakcji projekt

\footnotetext{
${ }^{4}$ Por. NSO, s. 343.

${ }^{5}$ Por. La I Conférence Panorthodoxe de Rhodos [1961], Catalogue des thèmes du pro-synode projeté, „Istina” 9 (1963) nr 1, s. 52-53.

${ }^{6}$ Por. Première Conférence Panorthodoxe Préconciliaire, Décisions [Chambésy, 28 novembre 1976], dz.cyt., s. 114.

${ }^{7}$ NSO, s. 343.
} 
dokumentu zachował zatem podwójny, przytoczony wyżej tytuł. Jego ostateczna wersja została przyjęta jednogłośnie przez zgromadzenie zwierzchników autokefalicznych Kościołów prawosławnych, obradujące w szwajcarskiej miejscowości Chambésy w dniach 21-28 stycznia 2016 roku$^{8}$.

\section{Struktura dokumentu}

Struktura dokumentu, przyjętego w 2016 roku, jest przejrzysta. Dokument składa się z sześciu części, opatrzonych literatami alfabetu: A. Wartość osoby ludzkiej (La valeur de la personne humaine), który liczy 4 punkty; B. Wolność i odpowiedzialność (Liberté et responsabilité), liczący 3 punkty; C. O pokoju i sprawiedliwości (De la paix et de la justice), liczy 5 punktów; D. Pokój i zapobieganie wojnie (La paix et la pévention de la guerre), liczy 3 punkty; E. Kościół prawosławny wobec dyskryminacji (L'Eglise Orthodoxe face aux discriminations), liczy 3 punkty; F. Misja Kościoła prawosławnego jako świadectwo miłości $\mathrm{w}$ diakonii (La mission de l'Eglise orthodoxe comme témoignage d'amour dans la diaconie), który liczy aż 15 punktów9

Język dokumentu nie jest scholastyczny, lecz raczej biblijno-narracyjny. Jego autorzy częściej odwołują się do ksiąg biblijnych niż do tekstów tradycji patrystycznej. Obecni są również Ojcowie Kościoła, tak bliscy tradycji prawosławnej, lecz przeważają zdecydowanie fragmenty z Pisma Świętego. Jest to tekst o charakterze pastoralnym, czyli takim, który zrozumieć może każdy wierzący, bez konieczności konsultacji słowników teologicznych czy innych. Autorzy używają języka zrozumiałego, ogólnie używanego i stąd łatwego do zrozumienia. To ważny aspekt tekstu, który przecież mówi o sprawach świata i o Kościele, który w nim żyje.

\footnotetext{
${ }^{8}$ Por. La mission de l'Église orthodoxe..., cyt.

${ }^{9}$ Por. La mission de l'Église orthodoxe..., cyt.
} 


\section{Kwestie teologiczne}

Pod ogólnym tytułem „kwestie teologiczne” chcę umieścić mój zachwyt i uwagi, które zrodziły się z uważnej lektury tekstu, które jednak nie mogły być nazbyt obszerne i szczegółowe, biorąc pod uwagę charakter niniejszego wystąpienia.

\section{Ouveture}

Przed podjęciem szczegółowych tematów misji Kościoła prawosławnego w świecie współczesnym autorzy dokumentu poświęcają jedną stronę tekstu wyjaśnieniu natury Kościoła, jego misji w świecie oraz jego relacji do królestwa Bożego. Kościół, który żyje „w świecie”, lecz „nie jest ze świata” (J 17, 11.14-15), który „,jest znakiem i obrazem królestwa Bożego w historii”, głosząc o „nowym stworzeniu” (2 Kor 5, 17), o „nowym niebie i nowej ziemi, gdzie mieszka sprawiedliwość” (2 P 3, 13), o świecie, w którym „Bóg otrze wszelką łzę z oczu ludzi, i śmierci już nie będzie; ani żałoby, ni krzyku, ni bólu już odtąd nie będzie” (Ap 21, 4-5)”, ma za zadanie gromadzić „razem” (1 Kor 11, 20) rozproszone dzieci Boże $(\mathrm{J} 11,52)$, bez względu na rasę, płeć, wiek, społeczny lub inny status, w jedno ciało, w jednej rzeczywistości pojednania, pokoju i miłości. Ponieważ Kościół pielgrzymuje „w świecie”, bliskie są mu jego problemy i troski jego mieszkańców. Lecz nie tylko nie pozostaje obojętny, ale - piszą autorzy dokumentu - Kościół bierze niejako na siebie, podobnie jak czynił to Chrystus, ich ból i rany. Podobny do dobrego Samarytanina, słowem „cierpliwości i pocieszenia” (Rz 15, 4; Hbr 13, 22), miłością i dobrocią niesie nadzieję na zwycięstwo dobra nad złem. Najważniejszą misją Kościoła nie jest zatem osądzać czy potępiać świat (J 3, 17 i 12,47), ale pouczać go, wzywać do nawrócenia i ciągle przypominać, że nie „można pozwolić, aby zło sterowało biegiem” historii. Pragnieniem Kościoła jest, aby „w świecie zapanowały pokój Boży, „który przewyższa wszelki rozum" (Flp 4, 7), pojednanie i miłość". Dokument nie mówi tego wprost, ale wyraźnie sugeruje, że pragnie tego również Jezus Chrystus. 
Tę cześć dokumentu nazwałem Ouverture. Rzeczywiście, przypomina on rodzaj wstępu, uwertury do opery muzycznej, która rozwija się w następnych numerach. Lecz już we wstępie zaznaczone zostają ramy tematyczne tekstu. Jego autorzy charakteryzują tożsamość Kościoła i świata, istniejące między nimi relacje, kwestie otwarte i cele, które mają za zadanie usprawiedliwić dialog Kościoła ze światem, uzasadnić jego pozycję mistrza i przewodnika, ale jednocześnie również rolę opiekuna, zatroskanego o dobro mieszkańców ziemi.

Można mówić o dość mocnym zbliżeniu tej części prawosławnego dokumentu do Wstępu watykańskiej konstytucji O Kościele w świecie wspótczesnym „Gaudium et spes”, który nosi tytuł Ścisła łączność Kościoła z cała rodzina narodów. Prawodawca uzasadniał, dlaczego Kościół katolicki zabiera głos w sprawach świata i jego mieszkańców. W przeciwieństwie jednak do dokumentu watykańskiego, prawosławni bliższy opis sytuacji człowieka w świecie, jak również omówienie problemów samego świata, zamieszczają nie w pierwszej części, jak czyniła to Gaudium et spes, ale w punkcie ostatnim (F).

W dokumencie Misja Kościoła prawosławnego w świecie wspótczesnym zastosowano metodę koła hermeneutycznego, ponieważ zanim autorzy dokumentu podejmą się w części ostatniej interpretacji fenomenów (zagrożeń), obecnych we współczesnym świecie, już od początku mają jasne wyobrażenie o nich, co wynika z ich wiedzy o świecie. Nie rozpoczynają procesu interpretacji świata i swojej w nim obecności od zera. Coś takiego byłoby niemożliwe bez uwzględnienia wcześniejszego rozumienia, które płynie z wiary i z Objawienia. Ich interpretacja świata, jego problemów i nadziei, jest więc procesem kolistym, ponieważ nie rozpoczyna się od punktu startowego, od całkowitej niewiedzy, ale zakłada wcześniejsze doświadczenia i dokonaną już interpretację sytuacji świata.

Zagadnienie obrazu i podobieństwa

W centrum prawosławnego zaangażowania w świecie znajduje się prawda o stworzeniu człowieka na „obraz i podobieństwo Boga" (por. Rdz 1, 26-27; 5, 1). Tematy, które interesują autorów 
dokumentu, dotyczą stworzenia „na obraz i podobieństwo” Boże, upadku człowieka i powrotu do jedności z Bogiem przez sakramenty, a następnie doprowadzenie go do pełni eschatologicznej. Spośród tych kwestii temat „obrazu i podobieństwa” zajmuje miejsce szczególne. Wierne nauce większości Ojców greckich, prawosławie utrzymuje, że obraz i podobieństwo nie są jedną i tą samą rzeczywistością ${ }^{10}$. Tak na przykład Jan Damasceński twierdził, że „wyrażenie “na obraz' oznacza rozumność i wolność, podczas gdy 'na podobieństwo' oznacza upodobnienie w porządku cnót"11. Z kolei Grzegorz Palamas uważał, że „w swoim bycie na obraz Boży człowiek przewyższa aniołów, lecz ustępuje im w podobieństwie, które jest w nim słabe i niestałe. [...] Po grzechu nie przestaliśmy wprawdzie być na obraz Boży, ale zatraciliśmy podobieństwo"12.

Dla myślicieli prawosławnych wyrażenie „na obraz” oznacza w gruncie rzeczy wolną wolę człowieka, jego rozum, umysł, jego poczucie moralnej odpowiedzialności za podejmowane lub niepodejmowane czyny. To właśnie stworzenie „na obraz” wyróżnia człowieka spośród wszystkich innych stworzeń, które wyszły z Bożej ręki. Ponieważ stworzony „na obraz Boży”, człowiek jawi się jako ktoś radykalnie in ny od tego, co go otacza i jest o s ob ą. Dar „obrazu” czyni człowieka kimś wyjątkowym, ale zarazem powołuje do bycia kimś jeszcze bardziej. On sprawia, że - jak pisał św. Makary z Egiptu - „między Bogiem a człowiekiem zachodzi najściślejsza więź pokrewieństwa"13 ${ }^{13}$ które jednak winno się ciągle rozwijać, wzrastać i jeszcze mocniej zakorzeniać w Bogu. Przez dar „obrazu” człowiek ontologicznie uczestniczy w tym, co boskie, a „obraz pociąga za sobą niezniszczalną obecność łaski wewnątrz ludzkiej natury”, jak pisze Evdokimov ${ }^{14}$.

${ }^{10}$ Por. Z. J. Kijas, Homo creatus est. Ekumeniczne studium antropologii Pawła A. Florenskiego († 1937) i Hansa Ursa von Balthasara († 1988), Kraków 1996, s. 39-77.

${ }^{11}$ Jan Damasceński, De fide orthodoxa, 1, II, c. XII, PG 94, 919b.

${ }^{12}$ Grzegorz Palamas, Physica, theologica, moralia et practica capita, PG 150, 1148b.

${ }^{13}$ Makary z Egiptu, Homilia XLV, PG 34, 790.

${ }^{14}$ P. Evdokimov, Kobieta i zbawienie świata, Poznań 1991, s. 68-69. 
Teologia prawosławna uczy, że jest czystą iluzją sądzić, iż człowiek niesie w sobie ostateczną rację bycia i wystarczającą zasadę istnienia. Tak myśląc, człowiek zacieśnia się do bezpłodnej i zarazem grzesznej, bo egoistycznej, samowystarczalności, której daleko do autentycznego istnienia, do przeżycia prawdy o własnej naturze. Życie dla siebie, czyli poza, czy wręcz przeciw prawdzie obrazu, jest rodzajem egzystencji zawieszonej, poruszającej się na powierzchni rzeczywistości, gdy tymczasem koniecznością jest zapuszczenie korzeni w samo źródło życia, tj. Boga. Wówczas dopiero pozorna i z gruntu egoistyczna egzystencja dla siebie, według własnych upodobań, ustępuje miejsca egzystencji autentycznej, tzn. egzystencji na miarę „obrazu”, która zarazem jest egzystencją dla: dla Boga i dla drugich. Człowiek otrzymał dar wolności, aby móc być całkowicie dla. Mówi bowiem prezentowany dokument:

„Dar wolności to jeden z największych darów Boga dla człowieka, rozumianego zarówno jako konkretny nosiciel obrazu Boga osobowego, jak i członek wspólnoty osób, będącej poprzez jedność rodzaju ludzkiego odzwierciedleniem przez łaskę życia w Trójcy Świętej i komunii Trzech Osób” (B.1).

Teologowie prawosławni - co powraca również w omawianym dokumencie - zgodnie przyznają, że dar obrazu, otrzymany przez człowieka w chwili stworzenia, charakteryzuje się pewną transcendencją ${ }^{15}$.W praktyce oznacza to, że w naturze obrazu leży wrodzona konieczność „przekraczania siebie”, a mówiąc innymi słowy, że człowiek stworzony na obraz nie pozwala, nie daje zamknąć się w sobie ani też zacieśnić wyłącznie do wąskich ram własnego ja. Dynamizując i aktywizując osobę, obraz pozwala jej „odkrywać się” w całej pełni w kimś drugim, a najbardziej we wspólnocie z Dawcą obrazu, czyli z Bogiem. To właśnie w jedności z Nim osoba osiąga największe piękno. Odsłaniając przed człowiekiem najgłębsze pokłady istnienia jako bytu ot wa rte go, ukierunkowanego i nastawionego na

${ }^{15}$ Por. Z. J. Kijas, Człowiek „obrazem i podobieństwem” Boga w prawosławnej teologii Pawła Florenskiego, „W Nurcie Franciszkańskim” 4 (1995), s. 74. 
dru gi e go, obraz daje mu możliwość uświadomienia jego autentycznego istnienia właśnie w relacji.

Kiedy teologia prawosławna mówi, że człowiek jest istnieniem w relacji, chce powiedzieć, że został on umieszczony na ziemi w roli pośrednika między światem widzialnym i niewidzialnym. Dokument wyraża tę prawdę słowami św. Grzegorza Teologa, który uczył, że Stwórca

„umieścił na ziemi człowieka, niczym drugi świat, makrokosmos w mikrokosmosie, niczym drugiego anioła, podwójną istotę stworzoną, by Go wielbić, strażnika świata widzialnego, wtajemniczonego w świat transcendentny, istotę królującą nad wszystkimi ziemskimi stworzeniami [...], żyjącą w tym świecie i aspirującą do innego, istotę dążącą do zjednoczenia z Bogiem poprzez przebóstwienie (Grzegorz Teolog, Mowa 45, 7: PG 36, 632AB)" (A.1).

W darze wolności kryje się jednak określone niebezpieczeństwo. Człowiek, zamiast Boga chwalić i uwielbiać, może Mu się sprzeciwić. Posiada on realną możliwość wystąpienia pr zeci iw Bogu i przeciw bliźniemu.

„Wolność - uczy dokument - czyni człowieka zdolnym do nieskończonego podążania ścieżką doskonalenia duchowego, ale zarazem niesie za sobą niebezpieczeństwo nieposłuszeństwa, ryzyko niezależności od Boga i w konsekwencji upadek, którego następstwem są tragiczne skutki zła w świecie" (B.1).

Konsekwencje takiego sprzeciwu są dramatyczne, nie tylko dla człowieka, ale także dla jego otoczenia, dla świata. Dokument powraca wielokrotnie do opisu dramatycznych skutków nieposłuszeństwa. Najwyraźniej jednak mówi o nich w części drugiej (B.), zatytułowanej Wolność $i$ odpowiedzialność. Jest ona jedną z najkrótszych części tekstu, ale niezwykle istotną dla całości. Porusza ona bowiem zagadnienie wolności, wcześniej już przypomniane, konsekwencje jej niewłaściwego użycia i wynikające stąd zadania dla człowieka i Kościoła. Już tytuł rozdziału wskazuje, że mowa w nim 
jest o wolności, negatywnych owocach i wynikającej stąd odpowiedzialności. Omawiając negatywne skutki użycia wolności, dokument charakteryzuje je następująco:

„Skutkami tego zła są niedoskonałości i braki cechujące nasze czasy, takie jak sekularyzacja, przemoc, rozluźnienie obyczajów, niezdrowe zjawiska związane z plagą narkotyków i innych uzależnień szerzących się wśród części dzisiejszej młodzieży, rasizm, zbrojenia, wojny i plagi społeczne przez nie wywołane, ucisk wobec niektórych grup społecznych, wspólnot wyznaniowych czy też całych narodów, nierówności społeczne, ograniczenia praw człowieka w zakresie swobody sumienia, a w szczególności swobody wyznania, dezinformacja i manipulowanie opinią publiczną, ubóstwo, niesprawiedliwy podział niezbędnych do przeżycia dóbr lub ich całkowity brak, głód milionów ludzi, przymusowe deportacje i handel ludźmi, nierozwiązane kwestie związane z uchodźcami, zniszczenie środowiska, niekontrolowane praktyki biotechnologii genetycznej i biomedycyny związane z początkiem, trwaniem i końcem życia ludzkiego - wszystko to podtrzymuje i potęguje lęki, będące udziałem ludzkości w naszych czasach" (B.2).

Sytuacja taka doprowadziła do degradacji pojęcia osoby ludzkiej, co z kolei nakłada na Kościół obowiązek głoszenia zdrowej nauki o tym, kim jest człowiek, jakie jest jego powołanie, jakiej pomocy udziela mu Bóg, aby odkrył w sobie pierwotną godność i najważniejsze cele w życiu. Kościół jest zobowiązany czynić to poprzez swoje słowo, służąc i dając świadectwo o wolności Chrystusa. Tekst nawołuje więc człowieka do mądrego, czyli odpowiedzialnego korzystania z wolności, ponieważ „wolność bez odpowiedzialności i bez miłości prowadzi ostatecznie do utraty wolności" (B.3).

Kwestia pokoju i potępienie wojny

Dokument poświęca wiele uwagi problematyce pokoju, stąd niektóre środowiska prawosławne oskarżały go o herezję irenizmu. Czy słusznie? Śmiem wątpić w zasadność takich oskarżeń, bo przecież pokój jest wartością nad wyraz chrześcijańską, od kiedy prorok Izajasz nazwał Zbawcę Księciem Pokoju” (Iz 9, 5). 
Cała trzecia część tekstu (C.), zatytułowana 0 pokoju i sprawiedliwości, porusza ważną tematykę pokoju i sprawiedliwości. W punkcie pierwszym tej części omówione zostają charakterystyczne rysy pokoju, jak rozumie go Kościół, pouczony przez swego Mistrza Chrystusa. To właśnie w świetle Jezusa Chrystusa tekst odróżnia pokój, o którym mówi świat, od pokoju, który daje Chrystus. Ten ostatni jest bowiem dojrzałym owocem

„rekapitulacji wszystkich rzeczy w Nim: godności i wielkości osoby ludzkiej, jako obrazu Boga; manifestacji organicznej jedności rodzaju ludzkiego i świata w Chrystusie, uniwersalności w ciele Chrystusa ideałów pokoju, wolności i sprawiedliwości społecznej; i na koniec płodności chrześcijańskiej miłości, jaka panuje między ludźmi i narodami. Prawdziwy pokój to owoc tryumfu na ziemi wszystkich tych chrześcijańskich ideałów" (C.1).

W kontekście całości omawianego dokumentu część poświęconą pokojowi i sprawiedliwości uznać można za obszerną. Liczy ona aż cztery mniejsze fragmenty, z których pierwszy - wyżej już omawiany - mówił o naturze pokoju, jakiego udziela Chrystus, drugi porusza kwestię ciągłej troski Kościoła o pokój, trzeci - konieczność „współdziałania ludzkiego" na rzecz pokoju. Akapit czwarty porusza zagadnienie grzechu, który - czytamy w dokumencie - jest „chorobą duszy, której widomymi objawami są konflikty, niezgoda, zbrodnie i wojny ze wszystkimi tragicznymi skutkami, jakie niosą ze sobą. Kościół próbuje leczyć nie tylko widome objawy tej choroby, lecz również samą chorobę, jaką jest grzech" (C.4).

Punkt piąty, ostatni, posiada formę swoistej deklaracji. Kościół prawosławny - czytamy w tym akapicie - „uważa za swój obowiązek wspieranie wszelkich realnych działań służących sprawie pokoju (por. Rz 14, 19) i torujących drogę sprawiedliwości, braterstwu, prawdziwej wolności i wzajemnej miłości wszystkich dzieci Jedynego Ojca Niebieskiego i wszystkich narodów, tworzących rodzinę ludzką" (C.5).

Przejście od tematyki pokoju do tematu zapobiegania wojnie wydaje się ze wszech miar naturalne i logiczne. To właśnie temat wojny jest treścią kolejnego rozdziału omawianego dokumentu (D.) 
Zaraz na wstępie pierwszego akapitu wojna zostaje potępiona jako konsekwencja zła i grzechu, której skutkiem są zniszczone relacje z Bogiem i stworzeniem. Wojny powodują ponadto śmierć ogromnej liczby osób, w ich następstwie pojawiają się nieuleczalne choroby, zmiany genetyczne, a także występują inne wydarzenia, które mają negatywne konsekwencje dla późniejszych pokoleń (por. D.1). Cerkiew prawosławna - czytamy w tekście - od zawsze potępiała wojnę, jako niezgodną z Bożą wolą i jako skutek istniejącego w świecie zła i grzechu. Równocześnie popierała wszelkiego rodzaju inicjatywy i wysiłki „mające na celu zapobieganie wojnie poprzez dialog i wszelkie inne właściwe sposoby” (D.2).

Kwestia „wojny nieuniknionej”

Dokument zakłada możliwość wojny „nieuniknionej” (inévitable), ale nie wyjaśnia bliżej jej sensu. Nie mówi nic, kiedy, w jakich warunkach wojna - którą się na ogół potępia - może być w jakimś stopniu „tolerowana” albo „dopuszczona”, ponieważ jest „nieunikniona”. Tekst nie podejmuje się opracowania tzw. „wojny sprawiedliwej”. Czy dla Kościoła prawosławnego istnieje zatem kategoria takiej wojny? Tylko bardzo zdawkowo omawiany dokument porusza kwestię słusznej obrony (osobistej czy narodowej) w przypadku zewnętrznego agresora, ale nie mówi nic o „granicach” takiej obrony. Myślę, że zagadnienie „wojny nieuniknionej” jest ważne i w sytuacji współczesnego świata wymagać ono będzie od teologów prawosławnych głębszej analizy. Ta część tekstu dokumentu zostaje zwieńczona stwierdzeniem:

„W przypadku gdyby wojna była nieunikniona, Kościół nie ustanie w modlitwie i duszpasterskiej opiece nad swymi dziećmi wplątanymi w wojenny konflikt, broniąc ich życia i wolności i podejmując wszelkie działania w celu jak najrychlejszego przywrócenia pokoju" (D.2).

Autorzy dokumentu przygotowawczego zdecydowanie potępiają różne konflikty i wojny, których przyczyną jest fanatyzm uzasadniany religijnie. Solidaryzują się z prześladowanymi chrześcijanami 
i wszystkimi, którzy doznają prześladowań, szczególnie w rejonie Bliskiego Wschodu.

Dość ogólne formy dyskryminacji

Część, w której omówiony zostaje stosunek Kościoła prawosławnego do problemu dyskryminacji (E.), nie należy do obszernych. W istocie zawiera jedynie trzy, raczej skromne, podpunkty. Autorzy wielokrotnie odwołują się w niej do tekstów biblijnych, głównie nowotestamentowych (raz tylko czytelnik zostaje odesłany do księgi Izajasza). Pomijają natomiast teksty Ojców Kościoła, którzy cytowani byli w punktach wcześniejszych częściej. Ponieważ autorzy dokumentu dość ogólnikowo odnoszą się do problemów współczesności, stosunkowo powierzchownie traktują również kwestie związane ze „źródłami” potencjalnej dyskryminacji ludzi. W punkcie pierwszym tego rozdziału dokument „odrzuca przemoc i niesprawiedliwość (Ps 10, 5.), potępia nieludzki stosunek do bliźniego (Mk 25, 41-46; Jk 2, 15-16)" i pisze, że w Kościele „nie ma miejsca na nienawiść lub wrogość, czy nietolerancję (Iz 11, 6; Rz 12, 10)" (E.1). W punkcie drugim, swoistym credo Kościoła prawosławnego o godności każdego człowieka, czytamy, że wierzy on, iż:

„Bóg «zjednego [człowieka] wyprowadził cały rodzaj ludzki, aby zamieszkiwał całą powierzchnię ziemi» (Dz 17, 26) i że w Chrystusie «nie ma już Żyda ani poganina, nie ma już niewolnika ani człowieka wolnego, nie ma już mężczyzny ani kobiety, wszyscy bowiem jesteście kimś jednym» (Ga 3, 28). Na pytanie: «A kto jest moim bliźnim?», Chrystus odpowiedział przypowieścią o dobrym Samarytaninie (por. Łk 10, 25-37). Wskazał nam w ten sposób, jak obalać bariery niechęci i uprzedzeń" (E.2).

Kościół wierzy mocno, że każdy człowiek, „,bez względu na kolor skóry, religię, rasę, płeć, narodowość, język, jest stworzony na obraz i podobieństwo Boże i jest równoprawnym członkiem wspólnoty ludzkiej”, dlatego „nie akceptuje dyskryminacji ze względu na wszystkie wyżej wymienione cechy, zakładającej różnice w godności między ludźmi" (E.2). 
Dokument nie omawia kwestii mniejszości seksualnych i nie podejmuje się wyraźnej oceny takich zjawisk, jak homoseksualizm, kwestia związków jednopłciowych, problem adopcji dzieci przez pary homoseksualne itd. Wiadomo skądinąd, że kwestie te były szeroko dyskutowane w trakcie prac przygotowawczych przez członków Komisji. Wywołały one również spore poruszenie w całym świecie prawosławnym, co prowadziło nierzadko do bardzo ostrej polemiki pomiędzy zwolennikami postaw bardziej czy mniej radyklanych i groziło wręcz podziałem wewnątrz samego Kościoła prawosławnego. Należy przypuszczać, że aby uniknąć głębszych podziałów, a zarazem nie musieć zrezygnować z samego dokumentu, Konferencja zdecydowała się odnieść do tej trudnej i delikatnej zarazem kwestii w dwóch różnych miejscach i z różnym odcieniem merytorycznym. W omawianym punkcie autorzy tekstu zastosowali daleko idącą ogólnikowość w ujęciu zagadnienia dyskryminacji. Ostatni punkt niniejszego rozdziału ujmuje całość kwestii w takich oto słowach:

„Kościół, respektując zasady praw człowieka i równego traktowania ludzi, stosuje te zasady w świetle swojej nauki o sakramentach, rodzinie, miejscu mężczyzny i kobiety w Kościele i o wartościach tradycji kościelnej. Kościół zastrzega sobie prawo dawania i daje świadectwo swojej wiary i nauki w przestrzeni publicznej" (E.3).

Z tekstu wynika, że z jednej strony Kościół prawosławny szanuje prawa i postawy ludzi, ale z drugiej strony rezerwuje sobie ich ocenę według swoich zasad. Dokument nie mówi jednak wyraźnie, jakie są i jak daleko idą owe „prawa człowieka” ani też jaka może być ich ocena ze strony Kościoła.

Dokument powraca do tej trudnej kwestii w ostatniej części (F), w numerze 14. Definiuje w nim chrześcijańskie rozumienie rodziny jako związku mężczyzny i kobiety i ocenia jako przeciwne nauce Kościoła wszystkie inne formy współżycia. Czytamy w tym punkcie, co następuje: 
„Przedłużenie odpowiedzialności duszpasterskiej Kościoła na Boską instytucję rodziny jest rzeczą całkowicie naturalną, gdyż zawsze opierała się ona na świętości sakramentu chrześcijańskiego małżeństwa, jako związku mężczyzny i kobiety, na wzór związku Chrystusa z Kościołem (por. Ef 5, 32). Nabiera to szczególnej aktualności w sytuacji, gdy w pewnych krajach podejmowane są próby zalegalizowania i teologicznego uzasadnienia form współżycia niezgodnych z chrześcijańską tradycją i doktryną" (F.14).

Być może przyszła dyskusja soborowa doprowadzi do opracowania bardziej szczegółowego „katalogu” praw człowieka i zasad równouprawnienia, których nie przygotowała Komisja, a o których wspomina. A może zadaniem prawosławnych moralistów będzie przyjść z pomocą wiernym w jasnej ocenie postaw przez wiarę akceptowanych i odrzucanych.

\section{Różne kierunki misji Kościoła}

Jest to ostatni i najbardziej obszerny rozdział dokumentu - liczy on aż 15 punktów. Jest w miarę kompletnym opisem sytuacji, w jakiej znalazł się współczesny świat i żyjący w nim człowiek. Tekst dokumentu odnosi się w równym stopniu do kwestii społecznych, moralnych, co ekonomicznych, ekologicznych czy bioetycznych. I chociaż od publikacji watykańskiego dokumentu Gaudium et spes upłynęło już przeszło pięćdziesiąt lat, to jednak w Misji Kościoła prawosławnego w świecie współczesnym odnaleźć możemy wiele elementów mu pochodnych, bliskich. Dla przykładu można wymienić kwestie życia gospodarczego, narastanie ogromnych różnic ekonomiczno-społecznych, konfrontacje i wrogość w świecie, równouprawnienie w korzystaniu z dóbr, polityka finansowa itd.

Omawiany dokument dla przyszłego Soboru Wszechprawosławnego nie zajął się szczegółowo kwestią ateizmu, której Sobór Watykański II w Gaudium et spes poświęcił kilka obszernych numerów (por. nr 19-21). Oczywiście, w niektórych partiach tekstu, aczkolwiek nie bezpośrednio i nie w sposób jasny, pojawiają się aluzje do tej problematyki. Daremne byłoby jednak szukanie jasnego opisu 
czy oceny kwestii ateizmu. Dlaczego? Może późniejsze komentarze do analizowanego dokumentu albo sama dyskusja soborowa wniosą coś więcej do tego tematu, którego nieobecność trochę dziwi. Dokument mówi o kulturze sekularyzacji czy konsumpcji, nie stawia jednak pytań o ich przyczynę (źródło) czy ich ewentualne skutki dla wiary. Zatrzymuje się na wyliczaniu fenomenów współczesności, ale nie pyta, skąd one przychodzą ${ }^{16}$.

Analizowany tekst pomija także - skądinąd ważną w aspekcie pokoju, jego przywrócenia, kiedy go brak, utrzymania lub umocnienia - kwestię zaangażowania się człowieka w życie publiczne i polityczne, również szeroko omawiane przez Vaticanum II. Sytuacja ta zdaje się sugerować, jakoby kwestia wspólnoty politycznej nie miała większej wagi dla prawosławia. Tekst nadmienia jedynie o możliwości i gotowości Kościoła prawosławnego do aktywnej współpracy z wszystkimi instytucjami w celu polepszenia warunków życia ludzi i umocnienia pokoju. Mówi:

„Wypełniając misję zbawczą w świecie, Kościół prawosławny aktywnie troszczy się o wszystkich potrzebujących pomocy, głodnych, chorych, niepełnosprawnych, o osoby starsze, prześladowane, pozbawione wolności, o więźniów, bezdomnych, osierocone dzieci, ofiary klęsk żywiołowych, konfliktów zbrojnych, handlu ludźmi i wszelkich form współczesnego niewolnictwa. Działania podejmowane przez Kościół prawosławny w walce ze skrajnym ubóstwem i niesprawiedliwością społeczną są wyrazem jego wiary i służbą samemu Bogu, który utożsamia się z wszystkimi ludźmi, a szczególnie zubogimi i nieszczęśliwymi: «Wszystko, co uczyniliście jednemu z tych braci moich najmniejszych, Mnieście uczynili» (Mt 25, 40). Kościół może współpracować z wszystkimi organizacjami społecznymi w całej różnorodności swojej społecznej posługi" (F.1).

Oddzielny punkt dokument poświęca tematyce środków społecznego przekazu, które określa „środkami masowej informacji”.

${ }^{16}$ Por. R. Preda, Orthodoxy Confronted with Ethical Questions: A Social-Theological Perspective, „St. Vladimir's Theological Quarterly” vol. 60 (2016), nr 1-2, s. 235-248. 
Są one używane przez współczesną kulturę, nazywaną w dokumencie kulturą sekularyzacji, konsumpcji i globalizacji, która prowadzi do utraty przez narody swoich duchowych korzeni, do historycznej amnezji i zapominania tradycji (por. F.7). Temat środków przekazu jest ważny. Są one narzędziami, których sposób użycia jest istotny i wpływa na pomnażanie lub obniżanie szacunku do wartości moralnych czy religijnych, rozbudzanie konfliktów lub ich gaszenie, przekazywanie prawdy lub fałszu. W gestii środków przekazu leży również troska o rodzinę i promocję jej godności. Czytamy w tekście:

„Media często dostają się pod kontrolę ideologii liberalnego globalizmu i zaczynają promować ideologię konsumpcji i niemoralności. Szczególny niepokój budzą przypadki traktowania wartości religijnych w sposób pozbawiony szacunku czy wręcz bluźnierczy, co prowadzi do waśni i niepokojów społecznych. Kościół przestrzega wiernych przed niebezpieczeństwem manipulowania sumieniami przez media, przed ich używaniem nie po to, by zbliżać ludzi, lecz po to, by nimi manipulować" (F.8).

Ostatni punkt (15) niniejszego dokumentu, zamykając w pewnym sensie koło hermeneutyczne, powraca do tematu początkowego, w którym niejako prezentował się Kościół prawosławny, mówiąc, kim jest i dlaczego, z jakiego tytułu czy też z czyjego polecenia wypowiada się na temat sytuacji panującej w świecie. We wstępie, który nazwałem Ouverture, tekst mówił, że Kościół żyje „w świecie”, lecz „nie jest z tego świata”, w punkcie ostatnim mówi się natomiast o spoczywającym na Kościele szlachetnym, proroczym obowiązku głoszenia Bożego słowa w każdym czasie i każdemu człowiekowi. Kościół jest zobowiązany głosić prawdę oraz napominać i zachęcać człowieka do powrotu na drogi dobra. Czytamy w tekście:

„W dzisiejszych czasach, jak zawsze, prorocki i kapłański głos Kościoła kieruje się do ludzkiego serca i wzywa, z apostołem Pawłem, do przyjęcia i przeżywania tego wszystkiego, «co jest prawdziwe, co godne, co sprawiedliwe, co czyste, co miłe, co zasługuje na uznanie» (Flp 4, 7), zbawczej 
miłości Ukrzyżowanego, jedynej drogi ku światu pokoju, sprawiedliwości, wolności i miłości między ludźmi i narodami” (F.15).

Dzięki Bożej miłości świat otrzymał w darze Kościół, który poruszony tą samą miłością głosi światu Ewangelię, oświeca umysł człowieka, uczy go, co jest dobre, a co złe, umacnia tych, którzy są słabi, podnosi upadłych, błądzących zaś wzywa do powrotu na drogi prawdy i dobra. Kościół nie chce i nie może zamknąć się w sobie, ale z woli swojego Założyciela musi żyć „w świecie” i kształtować ten świat „od środka”. Prezentowany projekt dokumentu dla przyszłego soboru jest więc ważnym głosem Kościoła prawosławnego, w który świat - niezależnie od tego, czy chce tego, czy nie - musi się wsłuchać.

\section{Bibliografia}

Damasceński Jan, De fide orthodoxa, PG 94, 789-1228.

Evdokimov P., Kobieta i zbawienie świata, Poznań 1991.

Harakas S., Reflections on the Ethical Dimensions of the Topics of the Great and Holy Synod, „The Greek Orthodox Theological Review” 24 (1979) nr 2-3, s. $144-155$.

Kałużny T., Nowy sobór ogólnoprawosławny. Natura, historia przygotowań, tematyka, Kraków 2008 [=NSO].

Kijas Z. J., Homo creatus est. Ekumeniczne studium antropologii Pawła A. Florenskiego († 1937) i Hansa Ursa von Balthasara († 1988), Kraków 1996.

Kijas Z. J., Człowiek „obrazem i podobieństwem” Boga w prawosławnej teologii Pawła Florenskiego, „W Nurcie Franciszkańskim” 4 (1995), s. 68-86.

La mission de l'Église orthodoxe dans le monde contemporain. La contribution de l'Église orthodoxe à la realisation de la paix, de la justice, de la liberté, de la fraternité et de l'amour entre les peuples et à la suppression des discriminations raciales et autres (Chambésy, 27 janvier 2016), https://mospat.ru/fr/2016/01/28/news127353/ (28.01.2016).

La I Conférence Panorthodoxe de Rhodos [1961], Catalogue des thèmes du pro-synode projeté, „Istina” 9 (1963) nr 1, s. 49-53. 
Lemopoulos G., Quelques réflexions sur les quatre textes de la Commission interorthodoxe préparatoire (Chambésy, février 1986), „Proche-Orient Chrétienne” 35 (1986), fasc. 3-4, s. 301-314.

Makary z Egiptu, Homilia XLV, PG 34, 790.

Palamas G., Physica, theologica, moralia et practica capita, PG 150, 1121-1226.

Preda R., Orthodoxy Confronted with Ethical Questions: A Social-Theological Perspective, „St. Vladimir's Theological Quarterly”, vol. 60 (2016) nr 1-2, s. 235248.

Première Conférence Panorthodoxe Préconciliaire [1976], Décisions [Chambésy, 28 novembre 1976], [w:] Synodica III, s. 113-117.

Schmemann A., Problem obecności Kościoła w świecie w świadomości prawosławnej, „Novum”, 12 (1978) nr 1, s. 52-76.

\section{L'Église orthodoxe en face les problèms du monde contemporain du point de vue d'un concile panorthodoxe}

\section{RESUMÉ}

Le document La Mission de l'Église Orthodoxe dans le monde contemporain contient les principes généraux, les objectifs et les tâches de la mission y étaient formulés ; la responsabilité missionnaire de l'Eglise. On y décrivait également les formes et les méthodes de l'activité missionnaire aujourd'hui. Le terme de « mission » vient du verbe latin « mittere », qui signifie « envoyer », et désigne une tâche confiée. Les apôtres (litt. « envoyés ») ont été les premiers missionnaires, appliquant ainsi le commandement donné par notre Seigneur et Sauveut Jésus Christ : «Allez, enseignez toutes les nations, les baptisant au nom du Père et du Fils et du Saint Esprit, et leur apprenant à observer tout ce que je vous ai prescrit » (Mt 28, 19-20). Mais aussi l"Église est appelée « apostolique », terme qui renvoie non seulement à la permanence de la foi et à la succession des ordinations depuis les apôtres, mais aussi à la vocation de l'Église, appelée à annoncer toujours la vérité chrétienne. Ainsi, la mission est inhérente à la nature même de l'Église : l'Église chrétienne est une Église missionnaire.

Le document dit que l'Église du Christ vit 'dans le monde', mais elle 'n'est pas de ce monde' (Jn. 17,11 et 14-15). L'Eglise constitue le signe et l'image du royaume de Dieu dans l'histoire, car elle annonce une 'nouvelle créature' 
(II Cor 5, 17), 'des cieux nouveaux et une terre nouvelle où la justice habite' (II P 3, 13), un monde dans lequel Dieu 'essuiera toute larme de leurs yeux, la mort ne sera plus, il n'y aura ni deuil, ni cri, ni souffrance' (Ap 21, 4-5).

Le document parle de la mission extérieure de l'Église qui s'adresse à ceux qui se situent hors de l'Église. Elle cible les adeptes de différentes doctrines et les porteurs de différentes idéologies, tant religieuses que laïques. Elle parle de la valeur de la personne humaine (A.), de la liberté et responsabilité (B.), de la paix et de la justice (C.), de la paix et de la prévention de la guerre (D.), de la tâche de l'Eglise Orthodoxe face aux discriminations (E.) et de la mission de l'Eglise orthodoxe comme témoignage d'amour dans la diaconie (F.). Le texte dit que «la voix prophétique et pastorale de l'Église s'adresse au cœur de l'homme et l'exhorte, avec l'apôtre Paul, à adopter et vivre « tout ce qui est noble, juste, pur, digne d'être aimé, d'être honoré » (Ph 4,7), l'amour sacrificiel de son Seigneur Crucifié, la seule voie vers un monde de paix, de justice, de liberté et d'amour entre les hommes et les peuples » (F 15).

MOTS-CLÉS: Councile panorthodoxe, Église orthodoxe, monde contemporain

SŁOWA KLUCZOWE: Sobór Wszechprawosławny, Kościół prawosławny, świat współczesny 